\title{
Increasing Indonesian Language Learning Results Models of Cooperative Learning Talking Stick Type
}

\section{Uswa Khasanah}

SDN Timbulsloko 1

uswakhasanah29@gmail.com

\section{Article History}

accepted 14/11/2020

approved $21 / 11 / 2020$

published 26/11/2020

\begin{abstract}
The purpose of this study was to improve the learning outcomes of students in the Indonesian language muple in grade II elementary schools with a cooperative talking stick learning model. The research carried out was to use two cycles of Classroom Action Research (CAR), with each cycle consisting of one meeting. The stages of each cycle are planning, implementing, observing and reflecting. Each meeting was conducted a knowledge test using formative tests and summative tests to determine the development of students. In the first cycle, the students who completed after carrying out the summative test were 62\%. In cycle II, students completed after carrying out summative tests of $86 \%$. These results indicate that the cooperative talking stick type learning model can improve student learning outcomes, especially the Class II Indonesian language muple at SD N TIMBULSOKO 1.
\end{abstract}

Keywords: Indonesia language, cooperative learning, talking stick

\section{Abstrak}

Tujuan dari penelitian ini adalah untuk meningkatkan hasil belajar peserta didik pada mupel Bahasa Indonesia di sekolah dasar kelas II dengan model pembelajaran cooperative talking stick. Penelitian yang dilakukan adalah dengan menggunaan Penelitian Tindakan Kelas (PTK) sebanyak dua siklus, dengan setiap siklusnya terdiri dari satu pertemuan. Tahapan setiap siklusnya adalah perencanaan, pelaksanaan, observasi dan refleksi. Setiap pertemuan dilakukan uji pengetahuan dengan mengguakan tes formatif dan tes sumatif untuk mengetahui perkembangan peserta didik. Pada siklus I peserta didik yang tuntas setelah melaksanakan tes sumatif sebesar $62 \%$. Pada siklus II peserta didik tuntas setelah melaksanakan tes sumatif sebesar $86 \%$. Hasil ini menunjukan bahwa model pembelajaran cooperative talking stick type dapat meningkatkan hasil belajar peserta didik khususnya mupel Bahasa Indonsia Kelas II di SD N TIMBULSOKO 1.

Kata kunci: Bahasa Indonesia, kooperatif learning, talking stick

Social, Humanities, and Education Studies (SHEs): Conference Series https://jurnal.uns.ac.id/shes 


\section{PENDAHULUAN}

Pelajaran Bahasa Indonesia bertujuan untuk menyiapkan peserta didik sebagai anggota masyarakat dan warga negara yang bisa berbahasa dengan baik dan berpengetahuan dalam masing-masing bidangnya. Dalam kehidupan sehari-hari Bahasa Indonesia sangat penting bukan berati bahasa daerah tidak penting itu juga penting.Berdasarkan Chaer (2006: 1), bahasa diartikan sebagai sistem lambang bunyi yang arbitrer, yang digunakan oleh anggota suatu masyarakat untuk bekerja sama, berinteraksi dan mengidentifikasi diri. Menurut Faisal (2009: 1-11) bahasa adalah alat komunikasi antara anggota masyarakat, berupa lambing bunyi, suara yang dihasilkan oleh alat ucap manusia.

Penerapan model pembelajaran yang kurang tepat dapat menyebabkan peserta didik yang kurang memperhatikan guru dalam menyampaikan materi dan keengganan peserta didik dalam bertanya kepada pendidik menyebabkan peserta didik kurang begitu menguasai materi. Hal ini menjadikan hasil belajar yang kurang maksimal terhadap mata pelajaran yang diajarkan..Dari hasil yang diperoleh dalam proses pembelajaran tentang menentukan kosakata ternyata kurang memuaskan, karena hanya 4 peserta didik dari 27 peserta didik yang dikatakan tuntas pada tes sumatif mata pelajaran Bahasa Indonesia. Menurut Sudjana (2010: 22), hasil belajar adalah kemampuan yang dimiliki peserta didik setelah menerima pengalaman belajar. Sehubungan dengan pendapat itu, maka Wahidmurni (2010: 18) menjelaskan bahwa sesorang dapat dikatakan telah berhasil dalam belajar jika ia mampu menunjukkan adanya perubahan dalam dirinya. Perubahan-perubahan tersebut di antaranya dari segi kemampuan berpikirnya, keterampilannya, atau sikapnya terhadap suatu objek.

Selama pembelajaran berlangsung, jarang peserta didik yang mengajukan pertanyaan atau memberikan tanggapan terhadap penjelasan pendidik. Rendahnya tingkat penguasaan peserta didik terhadap materi pelajaran yang disebabkan metode mengajar pendidik kurang tepat, peserta didik kelihatan pasif dan takut menjawab pertanyaan pendidik, peserta didik kurang antusias dalam proses pembelajaran, peserta didik tidak berani bertanya tentang materi yang belum jelas.

Ketidak berhasilan peserta didik memahami materi pelajaran disebabkan beberapa faktor pendidik dalam menyampaikan materi kurang sistematis / tidak sesuai skenario pembelajaran. pendidik lebih aktif dibanding peserta didik dan masih banyak menggunakan metode ceramah. Interaksi tanya jawab pendidik dan peserta didik masih kurang, pendidik kurang memotivasi peserta didik dalam proses pembelajaran dan alat peraga belum digunakan sebagaimana mestinya/secara maksimal oleh pendidik sehingga kurang dapat menarik perhatian peserta didik.

Untuk memperbaiki proses pembelajaran tersebut, Peneliti melakukan pembelajaran melalui pola Penelitian Tindakan Kelas (PTK) dengan dua siklus dengan model pembelajaran kooperatif tipe Talking Stick untuk meningkatkan aktifitas dan pemahaman peserta didik terhadap mata pelajaran Bahasa Indonesia materi menentukan kosakata dan konsep tentang lingkungan yang sehat dan tidak sehat di lingkungan sekitar di SD Negeri Timbulsloko 1 Kecamatan Sayung, Kabupaten Demak semester 1 Tahun Pelajaran 2020/2021.

\section{METODE}

Pembelajaran kooperatif berasal dari kata cooperative yang artinya mengerjakan sesuatu secara bersama-sama dengan saling membantu satu sama lainnya sebagai satu kelompok atau satu tim. Slavin mengemukakan, pembelajaran kooperatif adalah suatu model pembelajaran dimana kelompok belajar dan bekerja dalam kelompokkelompok kecil yang berjumlah empat orang secara kolaboratif sehingga dapat merangsang peserta didik lebih bergairah dalam belajar. Menurut Slavin (Isjoni, 2011:15) "In cooperative learning methods, students work together in four member 
teams to master material initially presented by the teacher". Wina Sanjaya (2010:246)

mengemukakan prinsip-prinsip pembelajaran kooperatif, yaitu: Saling ketergantungan positif, Tanggung jawab perseorangan, Tatap muka, Komunikasi antar anggota, Evaluasi proses kelompok. Ini berarti bahwa cooperative learning atau pembelajaran kooperatif adalah suatu model pembelajaran dimana sistem belajar dan bekerja kelompok-kelompok kecil berjumlah 4-6 orang secara kolaboratif sehingga dapat merangsang peserta didik lebih bergairah dalam belajar Analisis penelitian ini adalah analisis deskriptif kuantitafif kualitatif dimana dalam penelitian ini selain penyajian hasil berupa data maupun angka peneliti juga menentukan bagaimana cara pengolahan hasil penelitian yakni dengan membuat analisisnya dengan menerapkan model cooperative tipe talking stick Penelitian ini dilaksanakan pada peserta didik kelas II SD Negeri Timbulsloko 1 Tahun Pelajaran 2020/2021 selama dua siklus secara luring dengan satu pertemuan disetiap siklusnya. Siklus I dilaksanakan pada tanggal 16 November 2020. Siklus II dilaksanakan pada tanggal 23 November 2020. Teknik pengumpulan data yang dilakukan dengan observasi dan tes, baik tes formatif maupun tes sumatif.

\section{HASIL DAN PEMBAHASAN}

Bagian ini sebanyak 800-1000 kata. Pada bagian pembahasan, diuraikan hasil kajian/penelitian dan hubungannya dengan kerangka teori atau kajian empirik terdahulu. Pada bagian ini dapat mnyertakan tabel dan gambar secara ringkas. Contoh penyajian tabel dan gambar sebagai berikutPada siklus I pembelajaran dilaksanakan selama satu pertemuan, setiap pertemuan diadakan tes sumatif dan tes sumatif. Untuk mengetahui perkembangan peserta didik selama pembelajaran. Siklus I membahas materi tentang mengetahui tempat bermain yang bersih, berupa mengamati di teks dan gambar bagaiman ciri-ciri tempat bermain yang bersih dan sehat. Pembelajaran dengan model cooperative type talking stick dilaksanakan dengan 2 langkah secara berurutan mulai dari menentukan perencanaan, pelaksanaan, observasi dan refleksi. Proses belajar yang dibuat peserta didik adalah dengan peserta didik membaca teks, selain membaca teks penulis juga menamplkan beberapa gambar pada proses pembelajaran siklus 1 hal itu dilakukan agar peserta didik lebih memahami tentang tempat bermain yang bersih dan sehat. Berikut ini adalah hasil belajar peserta didik pada siklus I yang bisa dilihat pada tabel berikut.

Tabel 1. Hasil Belajar Peserta Didik Siklus I

\begin{tabular}{ccccccccc}
\hline & \multicolumn{3}{c}{ Tes formatif } & \multicolumn{4}{c}{ Tes sumatif } \\
Siklus I & \multicolumn{1}{c}{$\begin{array}{c}\text { Pesdik tuntas } \\
\text { Pesdik belum }\end{array}$} & $\begin{array}{c}\text { Pesdik tuntas } \\
\text { tuntas }\end{array}$ & $\begin{array}{c}\text { Pesdik belum } \\
\text { Pesduntas }\end{array}$ \\
& $\mathrm{Jml}$ & $\%$ & $\mathrm{Jml}$ & $\%$ & $\mathrm{Jml}$ & $\%$ & $\mathrm{Jml}$ & $\%$ \\
\hline Pertemuan 1 & 6 & 22 & 21 & 77 & 9 & 62 & 18 & 38 \\
\hline
\end{tabular}

Berdasarkan tabel di atas dapat dilhat terjadi peningkatan nilai pada pada peserta didik antara tes sumatif dan tes sumatif yaitu pada awal tes sumatif jumlah peserta didik yang tuntas hanya 6 dan 21 peserta didik yang belum tuntas. Kemudian, terjadi peningkatan yang signifikan pada tes sumatif jumlah peserta didik yang tuntas adalah 9 peserta didik dan 18 peserta didik belum tuntas. Dengan bantuan hasil analisis data yang diperoleh, peneliti mencoba merenungkan kembali pelaksanaan tindakan yang telah tercatat melalui observasi. Melalui refleksi peneliti dapat menentukan apa yang telah dicapai, apa yang belum dicapai, serta apa yang perlu diperbaiki lagi dalam 
pembelajaran selanjutnya. Hasil tes sumatif siklus I menunjukan hasil belajar berupa tingkat ketuntasan peserta didik sudah mengalami peningkatan, namun masih perlu perbaikan untuk siklus berikutnya, utamanya pentingnya pendidik untuk memberikan penguatan dan penekanan terhadap materi yang dipelajari, memberikan kesempatan kepada peserta didik untuk bertanya dan menyimpulkan materi pelajaran, menggunakan waktu secara efektif. Oleh karena itu peneliti berkesimpulan bahwa Model Pembelajaran Kooperatif Tipe Talking Stick yang digunakan pada siklus I sudah tepat, akan tetapi dalam pelaksanaan perlu diadakan peningkatan. Selanjutnya peneliti membuat rancangan penelitian Siklus II untuk meningkatkan hasil belajar peserta didik mengenai menentukan kosakata. Berikut ini adalah hasil belajar peserta didik pada siklus II yang bisa dilihat pada tabel berikut.

Tabel 2. Hasil Belajar Peserta Didik Siklus II

\begin{tabular}{|c|c|c|c|c|c|c|c|c|}
\hline \multirow{3}{*}{ Siklus II } & \multicolumn{5}{|c|}{ Tes formatif } & \multicolumn{3}{|c|}{ Tes sumatif } \\
\hline & \multicolumn{2}{|c|}{ Pesdik tuntas } & \multicolumn{2}{|c|}{$\begin{array}{c}\text { Pesdik belum } \\
\text { tuntas }\end{array}$} & \multicolumn{2}{|c|}{ Pesdik tuntas } & \multicolumn{2}{|c|}{$\begin{array}{l}\text { Pesdik belum } \\
\text { tuntas }\end{array}$} \\
\hline & $\mathrm{Jml}$ & $\%$ & $\mathrm{Jml}$ & $\%$ & $\mathrm{Jml}$ & $\%$ & $\mathrm{Jml}$ & $\%$ \\
\hline Pertemuan 1 & 12 & 44 & 15 & 55 & 20 & 86 & 7 & 14 \\
\hline
\end{tabular}

Berdasarkan tabel di atas maka terjadi peningkatan antara tes formatif dan tes sumatif pada pertemuan 1. Setiap peserta didik sudah mengalami peningkatan hasil belajarnya. Ketuntasan klasikal juga mengalami peningkatan, pada tes formatif terdapat 12 peserta didik yang sudah tuntas, dan 15 peserta didik belum tuntas. Akan tetapi, pada tes sumatif bertambah menjadi 20 peserta didik yang sudah tuntas dengan Kriteria Ketuntasan Minimal (KKM) sebesar 70. Dengan bantuan hasil analisis data yang diperoleh, peneliti mencoba merenungkan kembali pelaksanaan tindakan yang telah tercatat melalui observasi. Melalui refleksi peneliti dapat menentukan apa yang telah dicapai, apa yang belum dicapai, serta apa yang perlu diperbaiki lagi dalam pembelajaran selanjutnya.

Hasil tes formatif siklus II menunjukan hasil belajar berupa tingkat ketuntasan belajar sudah mengalami peningkatan yang lebih baik, baik dari pemberian konsep, cara bertanya, pengelolaan kelas, penggunaan media dan peraga serta perubahan model/ strategi yang di lakukan. Oleh karena itu peneliti berkesimpulan bahwa Model Pembelajaran Kooperatif Tipe Talking Stick yang digunakan pada siklus II sudah tepat, karena peserta didik diberi kesempatan untuk mendapatkan pengalaman yang nyata selama pembelajaran dan diberi kesempatan untuk berinterkasi dengan teman guna meningkatkan rasa percaya dirinya.Dari dua siklus yang sudah dilaksanakan.

\section{SIMPULAN}

Penerapan model pembelajaran kooperatif tipe Talking Stick dapat meningkatan hasil belajar Bahasa Indonesia tentang menenukan kosakata di Kelas II SD Negeri Timbulsloko 1 Kecamatan Sayung kabupaten Demak semester 1 tahun pelajaran 2020/2021. Langkah-langkah model pembelajaran kooperatif tipe Talking Stick yaitu: a) pendidik menyiapkan sebuah tongkat yang panjangnya $60 \mathrm{~cm}$, b) pendidik menyampaikan materi pokok yang akan dipelajari, kemudian memberikan kesempatan 
para kelompok untuk membaca dan mempelajari materi pelajaran, c) Peserta didik berdiskusi membahas masalah yang terdapat di dalam wacana, d) Setelah peserta didik selesai membaca materi pelajaran dan mempelajari isinya, pendidik mempersilahkan peserta didik untuk menutup isi bacaan. e) pendidik mengambil tongkat dan memberikan kepada salah satu peserta didik, setelah itu pendidik memberikan pertanyaan dan peserta didik yang memegang tongkat tersebut harus menjawabnya, demikian sampai sebagian besar peserta didik mendapat bagian untuk menjawab setiap pertanyaan dari pendidik. Peningkatan hasil belajar Bahasa Indonesia tentang menentukan kosakata dengan menggunakan model pembelajaran kooperatif tipe Talking Stick pada peserta didik Kelas II SD Negeri Timbulsloko 1 Kecamatan Sayung kabupaten Demak semester 1 tahun pelajaran 2020/2021 mampu meningkatkan hasil belajar peserta didik.

\section{DAFTAR PUSTAKA}

Chaer, Abdul. 2006. Tata Bahasa Praktis Bahasa Indonesia. Jakarta: PT Rineka Cipta. Faisal, dkk. 2008. Kajian Bahasa Indonesia SD. Jakarta: Direktorat Jendral Pendidikan Tinggi Departemen Pendidikan Nasional.

Isjoni. 2011. Pembelajaran Kooperatif, Meningkatkan Kecerdasan Komunikasi Antar Peserta Didik. Yogjakarta: Pustaka Pelajar.

Peraturan Menteri Pendidikan Nasional No 22. 2006. Standar isi untuk satuan pendidikan dasar dan menengah. Jakarta: Menteri Pendidikan Nasional.

Rosdiana, Yusi, dkk. 2009. Bahasa dan Sastra Indonesia di SD. Jakarta: Universitas Terbuka

Rudy Gunawan. 2011. Pendidikan Bahasa Indonesia Filosofi, Konsep, dan Aplikasi. Bandung: Alfabeta.

Rusman. 2012. Belajar dan Pembelajaran Berbasis Komputer Mengembangkan Profesionalisme Guru Abad 21. Bandung: Alfabeta.

Sudjana, N. 2009. Penilaian Hasil Proses Belajar Mengajar (Cetakan Ketigabelas). Bandung: PT Remaja Rosdakarya 